Supplement of Geosci. Model Dev., 14, 2235-2264, 2021

https://doi.org/10.5194/gmd-14-2235-2021-supplement

(C) Author(s) 2021. CC BY 4.0 License.

(c) (i)

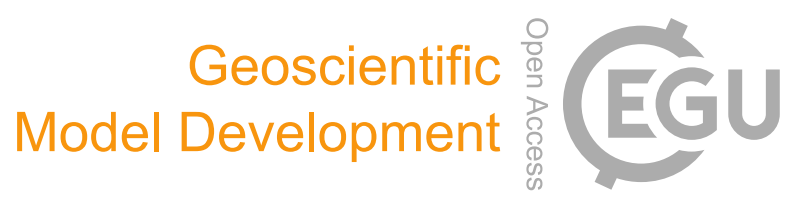

Supplement of

\title{
Comparison of three aerosol representations of NHM-Chem (v1.0) for the simulations of air quality and climate-relevant variables
}

Mizuo Kajino et al.

Correspondence to: Mizuo Kajino (kajino@mri-jma.go.jp)

The copyright of individual parts of the supplement might differ from the article licence. 


\section{Supplement 1}

Supplement 1 includes the description of the NHM (the Japan Meteorological Agency's Non-Hydrostatic Model)Chem model. Originally, the previous version of current manuscript was published in Geoscientific Model Development Discussion as a model description paper (Kajino et al., 2018; https://doi.org/10.5194/gmd-2018-128), but the revision was not accepted. The current version is a resubmission of Kajino et al. (2018), but as a model evaluation paper this time, based on the referees' comments. Thus, the model description part is separately written in this section.

Table S1-1 summarizes the schemes of the chemical transport model (CTM) and database available for NHM-Chem. The advection algorithm (Walcek and Aleksic, 1998) was used to determine advection by mean wind. The turbulent diffusion calculation utilized the forward-time central-space method using turbulent diffusivities predicted by meteorological models or calculated as a function of predicted turbulent kinetic energy (TKE) and mixing length, depending on the selection of the turbulence scheme of the meteorological models. The SAPRC99 gas-phase chemistry mechanism (Carter, 2000) was used with the photolysis rates predicted by Madronich (1987). The three heterogeneous chemical reactions of $\mathrm{N}_{2} \mathrm{O}_{5}, \mathrm{HO}_{2}$, and $\mathrm{NO}_{2}$ from Jacob (2000) were included in SAPRC99. The heterogeneous reaction rates were formulated as a function of aerosol surface area and independent of their substrates; same rates used for different aerosol surfaces composed of ammonium sulfate, organics, or mineral dust. The secondary organic aerosol (SOA) chemistry was predicted by Edney et al. (2007), and the liquid phase chemistry was predicted by Walcek and Taylor (1986) for inorganics and Carlton et al. (2007) for organics.

For the aerosol microphysics calculations, the triple-moment modal method (Kajino, 2011) was used. A log-normal size distribution was assumed for the aerosol populations. There are three parameters used to identify the log-normal function, namely, the number concentration, geometric mean diameter $D_{\mathrm{g}}$, and geometric standard deviation $\sigma_{\mathrm{g}}$. The three moments of the number, surface area, and mass concentrations of aerosols are selected to fix the log-normal parameters and are transported in the simulation. The variations in these three moments represent how the log-normal parameters of aerosol populations are changed in a physically consistent manner throughout the simulation. Although Kajino (2011) accounted for the fractal shapes of particles (as implemented by Kajino and Kondo, 2011 in the 3-D CTM framework), currently, all particles are assumed to be spherical for aerosol microphysics. A spherical shape is also assumed for the calculations of the optical and radiation properties of the aerosols. The aerosol microphysics calculation algorithm to calculate condensation, evaporation, and Brownian coagulation was described in detail by Kajino et al. (2012a). Kuang et al. (2008) was used to calculate the new particle formation as a function of sulfuric acid vapor. ISORROPIA2 (Fountoukis and Nenes, 2007) and Edney et al. (2007) were used to calculate the surface equilibrium vapor pressures of inorganic and organic compounds, respectively. The dry deposition velocities of gases were calculated by Zhang et al. (2003), and those of aerosols were calculated by a scheme developed based on Zhang et al. (2001) with modifications by Katata et al. (2008, 2011a) and Kajino et al. (2012a). The in-cloud scavenging process is composed of several elementary processes, namely, cloud condensation 
nuclei (CCN) activation (Abdul-Razzak and Ghan, 2000), ice nuclei (IN) activation (Lohmann and Diehl, 2006), and subsequent cloud microphysical processes (Lin et al., 1983). The subgrid-scale convection and scavenging were calculated by Pleim and Chang (1992).

Table S1-1: List of models, schemes, and databases available for NHM-Chem

\begin{tabular}{ll}
\hline Scheme/data & Name/reference \\
\hline Meteorological model $^{\mathrm{a}}$ & Nonhydrostatic model (NHM; Saito et al., 2006, 2007, Saito 2012) \\
Mascon model $^{\mathrm{b}}$ & MCWCM (Ishikawa, 1994) \\
Boundary concentrations & Climatological value or 3-hourly field obtained from MRI-CCM2 (Deushi and \\
& Shibata, 2011) and MASINGAR mk-2 (Tanaka et al., 2003, Tanaka and Ogi \\
& 2017, Yumimoto et al., 2017) \\
Emission & Anthropogenic (REASv2, Kurokawa et al., 2013; EAGrid, Kannari et al., 2007, \\
& Fukui et al., 2014), Biomass burning (GFED3, Giglio et al., 2010), Biogenic \\
& (MEGAN2, Guenther et al., 2006), Asian dust (Han et al., 2004), Sea-salt \\
& (Clarke et al., 2006) \\
Advection & MPMAA (Walcek and Aleksic, 1998) \\
Photolysis rate & Madronich (1987) with TOMS O3 column data \\
Gas chemistry & SAPRC99 (Carter, 2000) (72 species and 214 reactions) + Jacob (2000) \\
& heterogeneous reactions (3 reactions) \\
SOA chemistry & Edney et al. (2007) \\
Liquid chemistry & Walcek and Taylor (1986), Carlton et al. (2007) \\
New particle formation & Kuang et al. (2008) \\
Aerosol microphysics &
\end{tabular}

${ }^{a}$ Other models such as the Weather Research and Forecasting model (WRF; Skamarock et al., 2008), Asuca is a System based on a Unified Concept for Atmosphere (ASUCA; JMA, 2014; Aranami et al., 2015), and Scalable Computing for Advanced Library and Environment (SCALE; Nishizawa et al., 2015, Sato et al., 2015) can also be used for the offline coupled version. ${ }^{b}$ The mascon model is needed only for the offline coupled version after the vertical interpolation is made because the vertical coordinates of the NHM and CTM are different, so that the number of vertical levels or model top height can be reduced in the CTM. The mascon model is not needed for the online coupled version, as the vertical coordinates of the meteorological and chemical variables are the same. The model top height can also be reduced for the online version. ${ }^{\mathrm{c}}$ Not used in the bulk method. Used in the 5-category and 3-category methods. 
Most of the above processes are similar to those used by Kajino et al. (2012a), whereas the fog deposition parameterization of Katata et al. (2015) and a detailed below-cloud scavenging scheme are also incorporated in this study, as described below.

Katata et al. (2015) developed a parameterization to calculate the fog deposition velocity as a function of the land use category (LUC), leaf area index (LAI), atmospheric stability, and 10-m wind speed. Fog deposition is calculated only in the bottom layer of the model when the cloud water content is greater than $10^{-5} \mathrm{~kg} \mathrm{~kg}^{-1}$ (Kajino et al., 2019). In island countries, such as Japan in the western Pacific, ground surfaces are often covered with humid mountain forests, and the contribution of fog deposition is ubiquitous.

The large discrepancy between the theoretical and experimental rates of below-cloud scavenging has been a critical issue and has not yet been resolved (Wang et al., 2010; Zhang et al., 2013). The theoretical rates are sometimes one to two orders of magnitude smaller than the empirical rates, especially for aerosols that are in the diameter ranges of approximately $1 \mu \mathrm{m}$, where Brownian motion and an inertial force are both small. In the current implementation, we proposed two options for below-cloud scavenging, namely, the conventional modal method developed by Kajino and Kondo (2011) and a newly implemented method using detailed size-resolved parameterizations. The latter size-resolved option requires a longer computational time, but the Gauss-Hermite quadrature method is used to minimize the computational time (however, it is still computationally expensive). Slinn's (1984) parameterization, which considers thermophoresis, diffusiophoresis, and electrostatic forces (Andronache et al., 2006), is used for the derivation of the collection efficiencies of aerosols by rain droplets. There are two options to calculate the efficiencies collected by snow and graupel particles, i.e., those of Slinn (1984) and Murakami (1985). In this study, we used the approach presented by Kajino and Kondo (2011) because of its computational efficiency.

Many of the schemes are similar or almost equivalent to those implemented in widely used regional community models, such as CMAQ (Byun and Schere, 2006; Wong et al., 2012) and WRF-Chem (Grell et al., 2005; Chapman et al., 2009), as seen from the result of a multi-CTM intercomparison study (Li et al., 2019; Chen et al., 2019; Itahashi et al., 2020; Kong et al., 2020; Tan et al., 2020; Ge et al., 2020): NHM-Chem behaved similarly to the other models, including CMAQ and WRF-Chem. The advantage of the current model is not considerable, except for the detailed fog deposition and belowcloud scavenging parameterizations. In fact, the fog deposition scheme for liquid water is already implemented in WRF (Katata et al., 2011b) but not in WRF-Chem to simulate the fog deposition of various chemical compositions. The resulting disadvantage is the underestimation of SOA formation in the current model. Although their formation mechanisms are still unknown, a volatility-based set SOA formation model (Donahue et al., 2006) was developed to improve the significant underestimation of conventional models already implemented in CMAQ and WRF-Chem, but not in NHM-Chem. 
The source code structure of NHM-Chem was designed for the seamless development of online and offline coupling, as presented in Fig. S1-1. The codes are written in Fortran 90. The offline and online NHM-Chem share common subroutines (or physical/chemical schemes). The chemistry-to-meteorology feedback process has not been included and will be implemented in the near future. The online version of NHM-Chem is currently a so-called 1-way (meteorology to chemistry) online coupled model.

(a) Online coupled NHM-Chem

(b) Offline coupled NHM-Chem

(c) Offline coupling with other met models
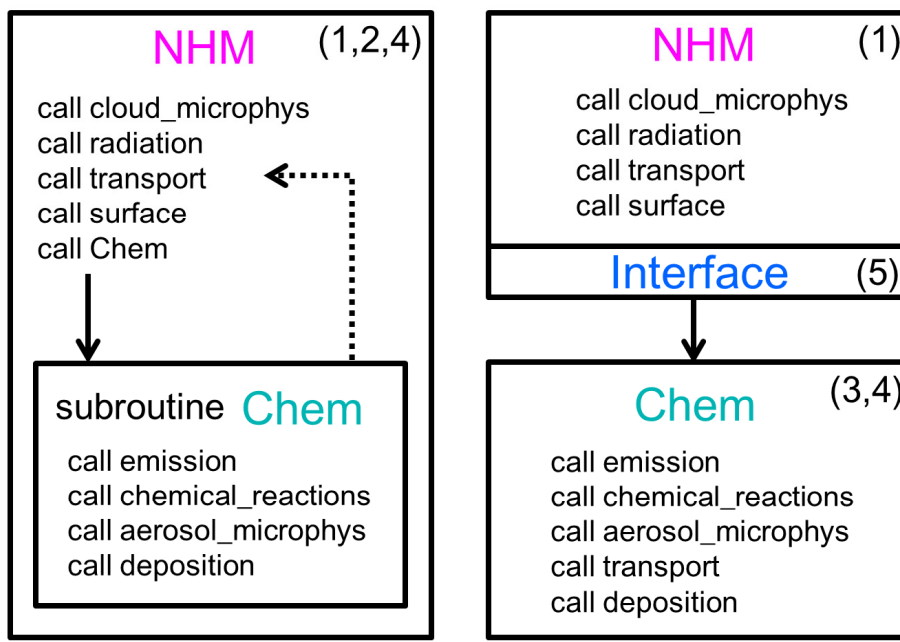

(1)

call cloud_microphys call radiation call transport call surface
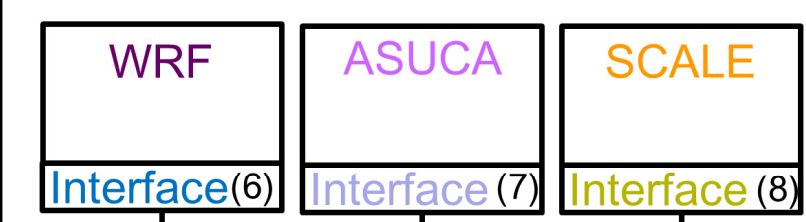

(-...2-way (chem to met) feedback was not implemented

Source code trees
(1) $\mathrm{Src} / \mathrm{NHM} /$
(2) Src/Chem_online/
(3) Src/Chem_offline/
(4) Src/Chem_common/
(5) Src/Interface/
(6) Src/Interface_for_WRF/
(7) Src/Interface_for_asuca/ convert_asuca.f90
(8) Src/Interface_for_SCALE/ convert_scale.f90

Figure S1-1. Online/offline coupling framework of NHM-Chem v1.0.

Online and offline coupling have different advantages and disadvantages. In online coupling, changes in meteorological fields affect chemical fields at small time steps (a few seconds) (e.g., Grell et al., 2005), whereas in offline coupling, changes in meteorological fields are interpolated between crude input/output time steps (an hour to a few minutes) (e.g., Byun and Schere, 2006). Certainly, chemistry-to-meteorology feedback processes cannot be readily implemented in the offline coupled framework but has been implemented in many of the online models (so-called 2-way (meteorology to chemistry/chemistry to meteorology) online coupled models, e.g., Chapman et al., 2009; Vogel et al., 2009; Wong et al., 
2012). Online coupling is slightly more time consuming if sensitivity tests in chemical fields are conducted: meteorology simulations are conducted for every sensitivity simulation in online coupling, whereas meteorological simulations are needed only once for offline coupling.

In the offline-coupling framework, a multimeteorological model intercomparison can be readily performed: we only need an interface to convert a meteorological model output to a chemical model input. Currently, interfaces with WRF, ASUCA, and SCALE are available in NHM-Chem. Kajino et al. (2019) evaluated the impact of the uncertainty in meteorological simulations on the modeling of chemical transport and deposition by using NHM, NHM-LETKF (Local Ensemble Transform Kalman Filter data assimilation method coupled with NHM; Kunii, 2014; Sekiyama et al., 2015), and WRF with several combinations of turbulence and cloud microphysics modules. For the offline coupled NHM-Chem, the horizontal grid of the CTM is identical to that of meteorological models, but the vertical coordinate is different; thus, users can reduce the number of vertical layers or the model top height for the computational efficiency, or they can use different meteorological models that use different vertical coordinates. To reduce the mass divergence due to vertical interpolation to approximately $10^{-5}$ to $10^{-6}\left(\mathrm{~s}^{-1}\right)$, the mass continuity model (Ishikawa, 1994) is incorporated into the meteorology-chemistry model interface of the offline coupled NHM-Chem, as shown in Table S1-1. For the online coupled NHM-Chem, the mass continuity model is not needed because the vertical coordinates of the CTM and NHM are common, but the model top layers of the CTM can be reduced for computational efficiency. 


\section{Supplement 2}

Supplement 2 includes the locations of the six major $\mathrm{SO}_{2}$-emitting volcanoes and the time series of the temporally smoothed and raw $\mathrm{SO}_{2}$ emission flux and smoke height data measured by the JMA and used in the NHM-Chem model. The locations and periods of the volcanic data are summarized in Table S2-1.

Table S2-1: Availability of volcanic emission data in Japan and time-averaged continuous $\mathrm{SO}_{2}$ emissions from the 1970 s to 1997, with the maximum values of the emissions since the 2000s provided in brackets.

\begin{tabular}{|c|c|c|c|c|c|}
\hline Volcano & $\begin{array}{l}\text { Longitude } \\
\text { (E) }\end{array}$ & $\begin{array}{l}\text { Latitude } \\
(\mathrm{N})\end{array}$ & $\begin{array}{l}\text { Height } \\
\text { (m MSL) }\end{array}$ & $\begin{array}{l}\mathrm{SO}_{2} \\
\text { emission } \\
\left(\text { ton } \mathrm{d}^{-1}\right)^{\mathrm{a}}\end{array}$ & $\begin{array}{l}\text { Period } \\
\text { ( } \mathrm{SO}_{2} \text { emission, } \\
\text { smoke height) }\end{array}$ \\
\hline $\begin{array}{l}\text { Miyakejima } \\
\text { (Mt. Oyama) }\end{array}$ & $139^{\circ} 31^{\prime}$ & $34^{\circ} 05^{\prime}$ & $775^{\mathrm{b}}$ & $\begin{array}{l}270 \\
(82,200)\end{array}$ & $\begin{array}{l}\text { August 26, } 2000 \text {-August 16, } 2018 \\
\text { January 1, } 2008 \text { - February 29, } 2016\end{array}$ \\
\hline Mt. Asama & $138^{\circ} 31^{\prime}$ & $36^{\circ} 24^{\prime}$ & 2,568 & $\begin{array}{l}370 \\
(8,700)\end{array}$ & $\begin{array}{l}\text { July 4, } 2002-\text { August } 20,2018 \\
\text { January } 1,2008 \text { - February } 29,2016\end{array}$ \\
\hline Mt. Aso & $131^{\circ} 06^{\prime}$ & $32^{\circ} 53^{\prime}$ & 1,592 & $\begin{array}{l}27 \\
(15,000)^{d}\end{array}$ & $\begin{array}{l}\text { March 22, } 2007 \text { - August 16, } 2018 \\
\text { January 1, } 2008 \text { - February 29, } 2016\end{array}$ \\
\hline $\begin{array}{l}\text { Mt. Kirishima } \\
\text { (Shinmoedake) }\end{array}$ & $130^{\circ} 52^{\prime}$ & $31^{\circ} 56^{\prime}$ & 1,420 & $\begin{array}{l}-\mathrm{e} \\
(34,100)^{\mathrm{f}}\end{array}$ & $\begin{array}{l}\text { January 27, } 2011 \text { - June 1, } 2018 \\
\text { January 1, } 2008 \text { - February } 29,2016\end{array}$ \\
\hline Mt. Sakurajima & $130^{\circ} 39^{\prime}$ & $31^{\circ} 35^{\prime}$ & 1,117 & $\begin{array}{l}1,900^{\mathrm{e}} \\
(7,400)\end{array}$ & $\begin{array}{l}\text { May 23, } 2007 \text { - July } 26,2018 \\
\text { January 1, } 2008 \text { - February } 29,2016\end{array}$ \\
\hline Kuchinoerabujima & $130^{\circ} 11^{\prime}$ & $30^{\circ} 28^{\prime}$ & 649 & $\begin{array}{l}570 \\
(3,100)\end{array}$ & $\begin{array}{l}\text { October 4, } 2008 \text { - July 13, } 2018 \\
\text { January 1, } 2008 \text { - February 29, } 2016\end{array}$ \\
\hline
\end{tabular}

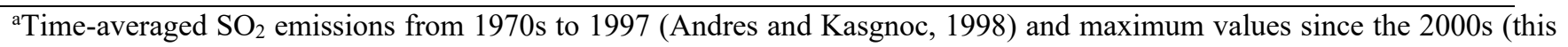
study).

${ }^{\text {bPreviously }} 814 \mathrm{~m}$, before a large eruption occurred in 2000.

${ }^{\mathrm{c} A n d r e s}$ and Kasgnoc (1998) also provide the sporadic emission amount for Mt. Aso.

${ }^{\mathrm{d}}$ The maximum value is not shown in Fig. S2-2 but it was observed on October 7, 2016.

${ }^{\mathrm{e}}$ Andres and Kasgnoc (1998) does not separate emissions from the two volcanoes, but the emission amount is supposed to be associated with Mt. Sakurajima.

${ }^{\mathrm{f}}$ The maximum value is not shown in Fig. S2-2 but was observed on March 7, 2018.

The locations of the volcanoes are depicted in Fig. S2-1. The time series of the smoothed volcanic $\mathrm{SO}_{2}$ emissions and smoke height data, together with the raw data, are illustrated in Figs. S2-2 and S2-3, respectively. The spline interpolation failed for the Kirishima volcano case, as its emissions were considerable but sporadic. The linear interpolation or periodical average should be used for the case. The volcanic emissions from other volcanoes worldwide are taken from Andres and Kasgnoc (1998). The volcanic emissions were uniformly allocated from the bottom layer to the smoke height or to $1,000 \mathrm{~m}$ AGL when smoke height information was not available. 
$\triangle \mathrm{SO}_{2}$-emitting volcanoes

(m)

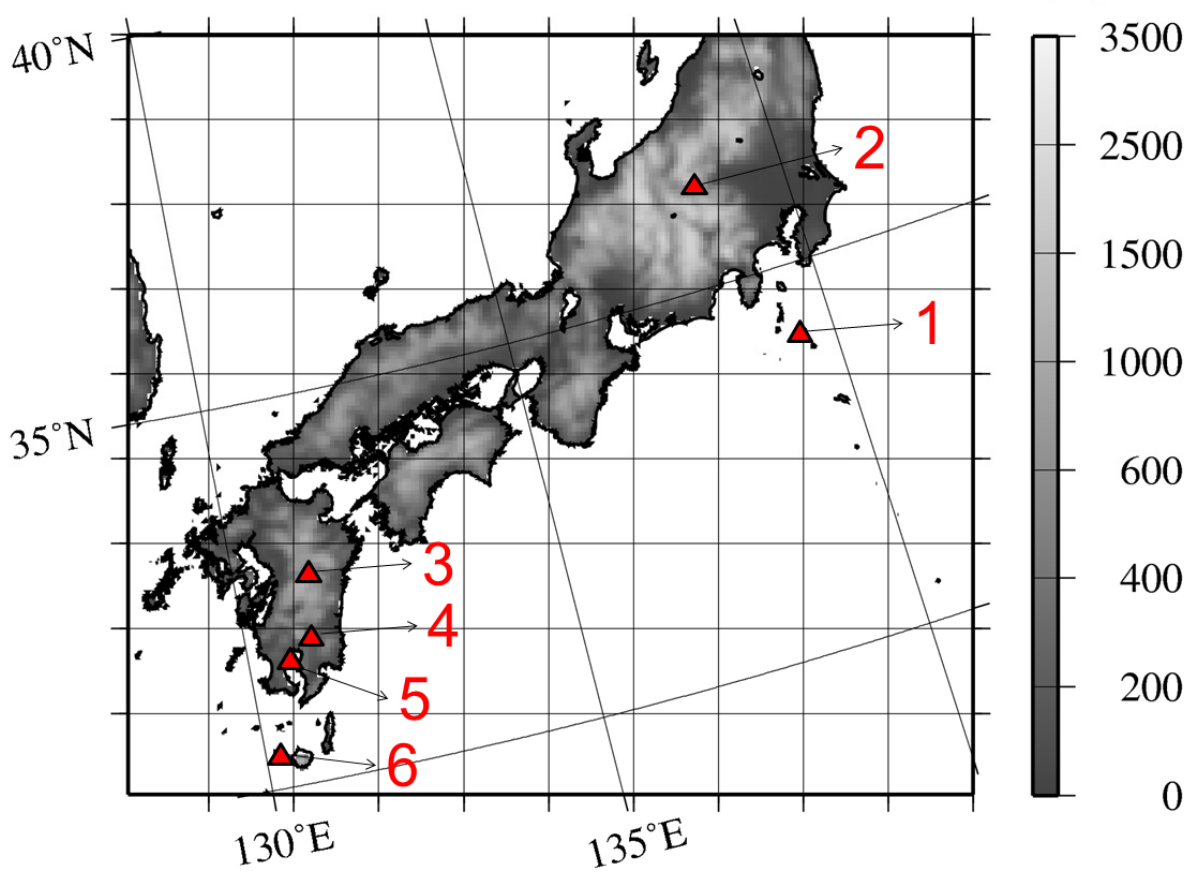

1. Miyakejima (Mt. Oyama), 2. Mt. Asama, 3. Mt. Aso,

4. Mt. Kirishima (Shinmoedake), 5. Mt. Sakurajima,

6. Kuchinoerabu-jima (Shindake)

Figure S2-1: Locations of the six $\mathrm{SO}_{2}$-emitting volcanoes in Japan monitored by the JMA. 
(a) Miyakejima (Mt. Oyama) (1)

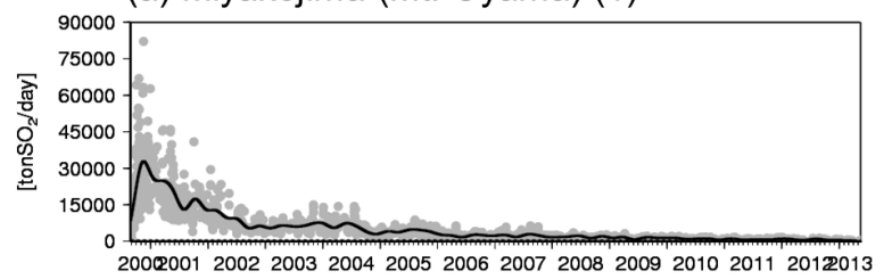

(c) Mt. Asama (2)

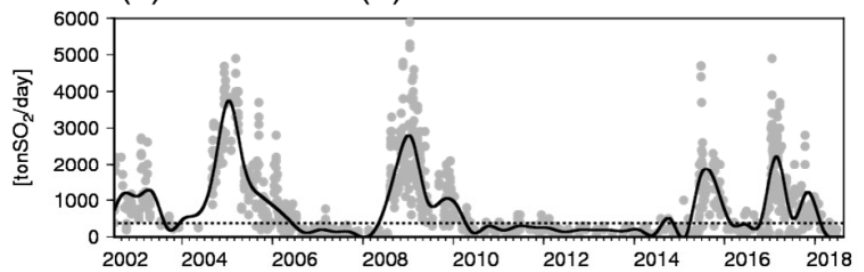

(e) Mt. Kirishima (Shinmoedake)

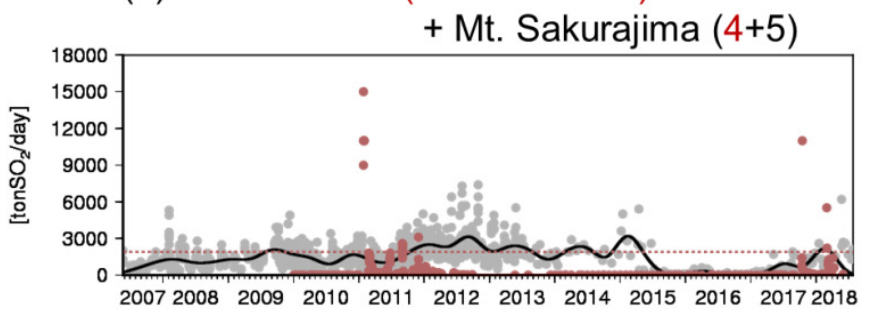

(b) Miyakejima (Mt. Oyama) (2007-) (1)

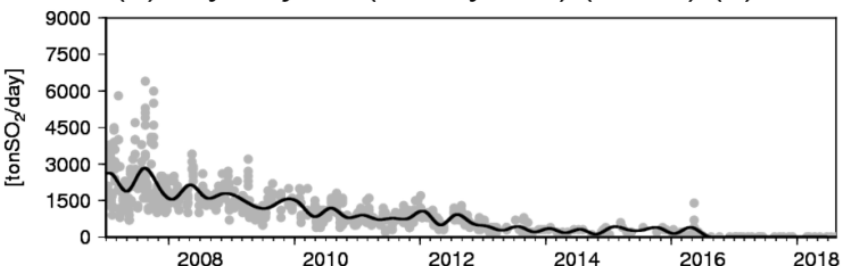

(d) Mt. Aso (3)

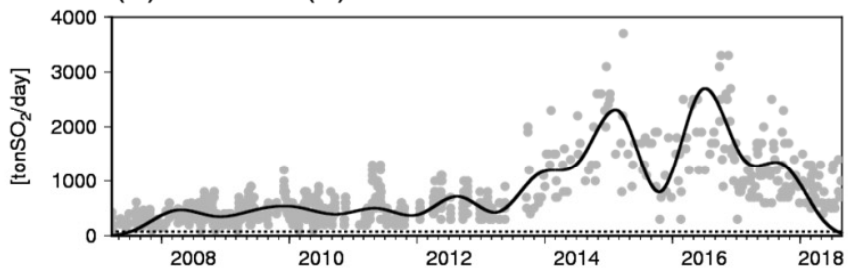

(f) Kuchinoerabujima (Shindake) (6)

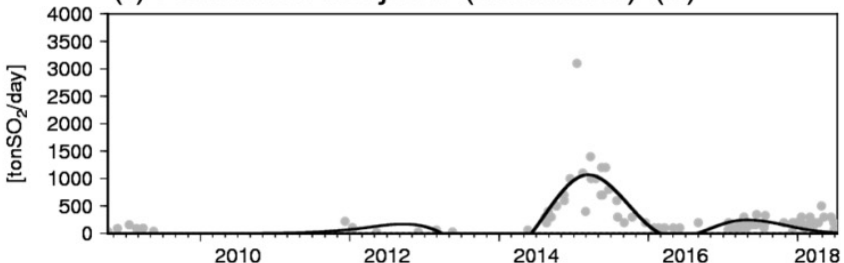

Measured by COSPEC Smoothed using cubic spline function

Andres and Kasgnoc (1998)

Figure S2-2: The time series of temporally smoothed data (solid line), with the raw data (gray dots) and estimations of Andres and Kasgnoc (1998) (dotted line), of the $\mathrm{SO}_{2}$ emission flux, measured by the JMA and used in the NHM-Chem model. The red dot in Fig. S2-2e is the sum of Mt. Kirishima and Mt. Sakurajima because Andreas and Kasgnoc (1998) do not differentiate emissions from the two volcanoes (associated with the eruption of Mt. Sakurajima). The smoothed interpolation for Mt. Kirishima is not shown in Fig. S2-2e because the time variation is sporadic; thus, spline smoothing failed and linear interpolation was used. 
(a) Miyakejima (Mt. Oyama) (1)

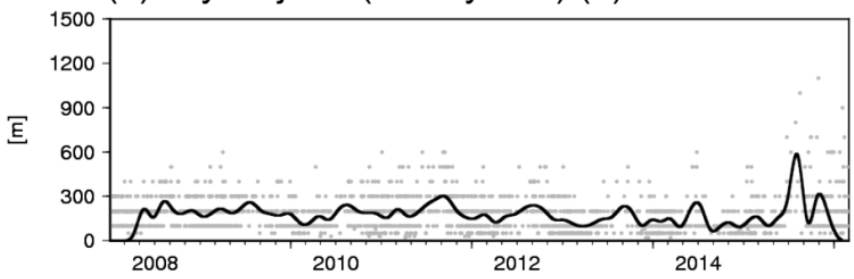

(c) Mt. Aso (3)

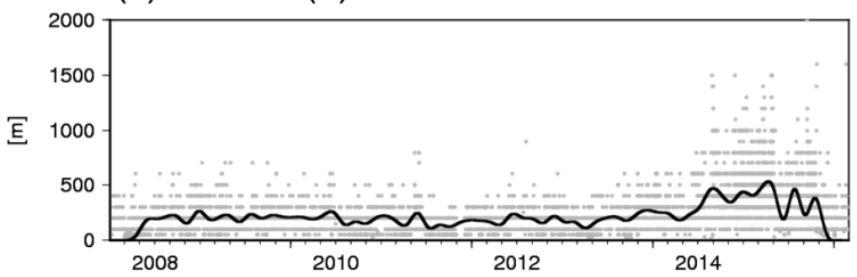

(e) Mt. Sakurajima (5)

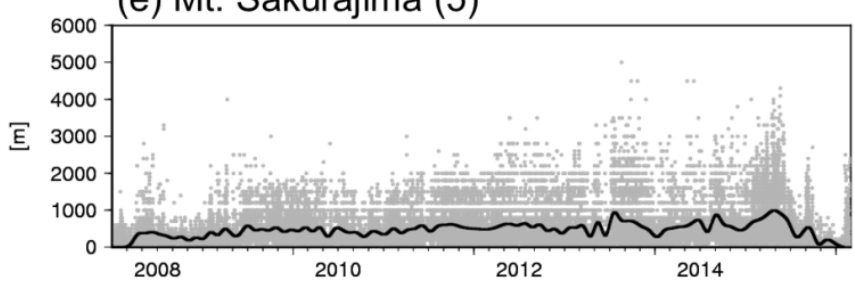

(b) Mt. Asama (2)

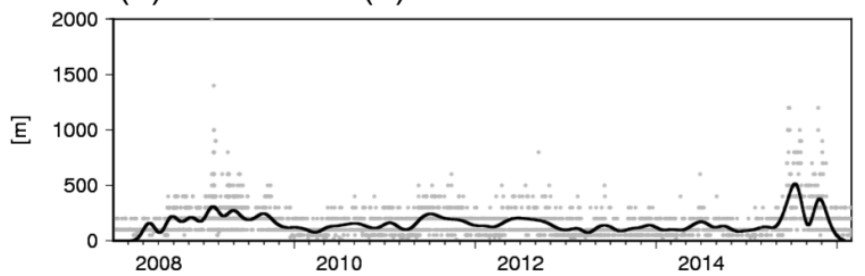

(d) Mt. Kirishima (Shinmoedake) (4)
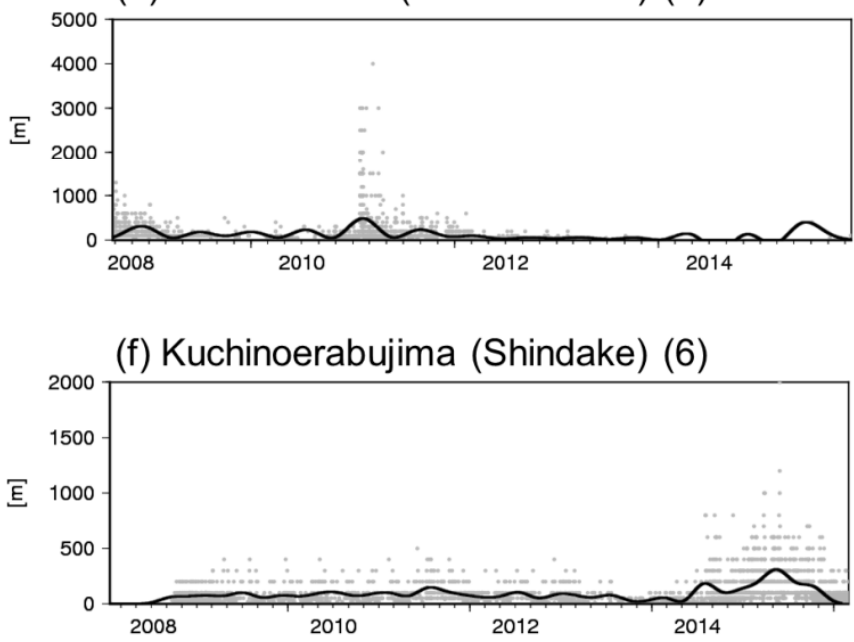

Measured Smoothed using cubic spline function

Figure S2-3: The time series of temporally smoothed data (solid line), with the raw data (gray dots) of the observed smoke height measured by the JMA and used in the NHM-Chem model. 


\section{Supplement 3}

Supplement 3 summarizes comparisons between the simulated and observed variables used for the discussion in Sect. 6, together with the relevant variables, such as $\mathrm{O}_{3}$ and its precursor gas $\mathrm{NO}_{\mathrm{x}}$, dust extinction coefficient (Ext_D) and PM 10 including the dust events of April 2006 (as defined in Sect. 6.2), $\mathrm{PM}_{2.5}$, wet deposition amounts of $\mathrm{SO}_{4}{ }^{2-}, \mathrm{NO}_{3}{ }^{-}$, and $\mathrm{NH}_{4}^{+}$, AOT, SSA, total (dust and spherical) extinction coefficient (Ext_T), $\mathrm{NC}_{0.3}$, and $\mathrm{PM}_{10}$ during the period when the OPC data were available. Statistical measures for the comparisons are listed in Table 4.

The simulated seasonal mean surface $\mathrm{O}_{3}$ concentration over China was highest in the summer but that in Japan was highest in the spring due to the long-range transport associated with traveling disturbances (Fig. 3, Fig. S3-1). Figure S3-1 compares the observed and simulated daily $\mathrm{O}_{3}$ concentrations with the precursor gas $\mathrm{NO}_{\mathrm{x}}$ concentrations at the Japanese EANET stations, and the statistical scores are shown in Table 4. The simulated medians agreed well with those observed medians (Sim:Obs of $\mathrm{O}_{3}$ and $\mathrm{NO}_{\mathrm{x}}$ are approximately 0.9 ), although the correlation coefficients were not very large (approximately 0.6 and 0.4 for $\mathrm{O}_{3}$ and $\mathrm{NO}_{x}$, respectively). The low correlation coefficients of $\mathrm{O}_{3}$ were due mainly to the locations of the observation sites: $R$ at remote island sites (Rishiri, Sado, Oki, Ogasawara, and Hedo in Fig. 2) was 0.76-0.91, whereas $R$ at rural inland sites (Happo and Yusuhara in Fig. 2) was low (0.24-0.49) due to the complex topography that cannot be resolved by the crude resolution of the current simulation. Low correlations of $\mathrm{NO}_{\mathrm{x}}$ were obtained mainly because it is difficult to simulate primary short-lived species for the crude resolution models. The unresolvable heterogeneity of emission sources near the sites degraded the model performance of the primary species results more than they did for the secondary species such as $\mathrm{O}_{3}$. 

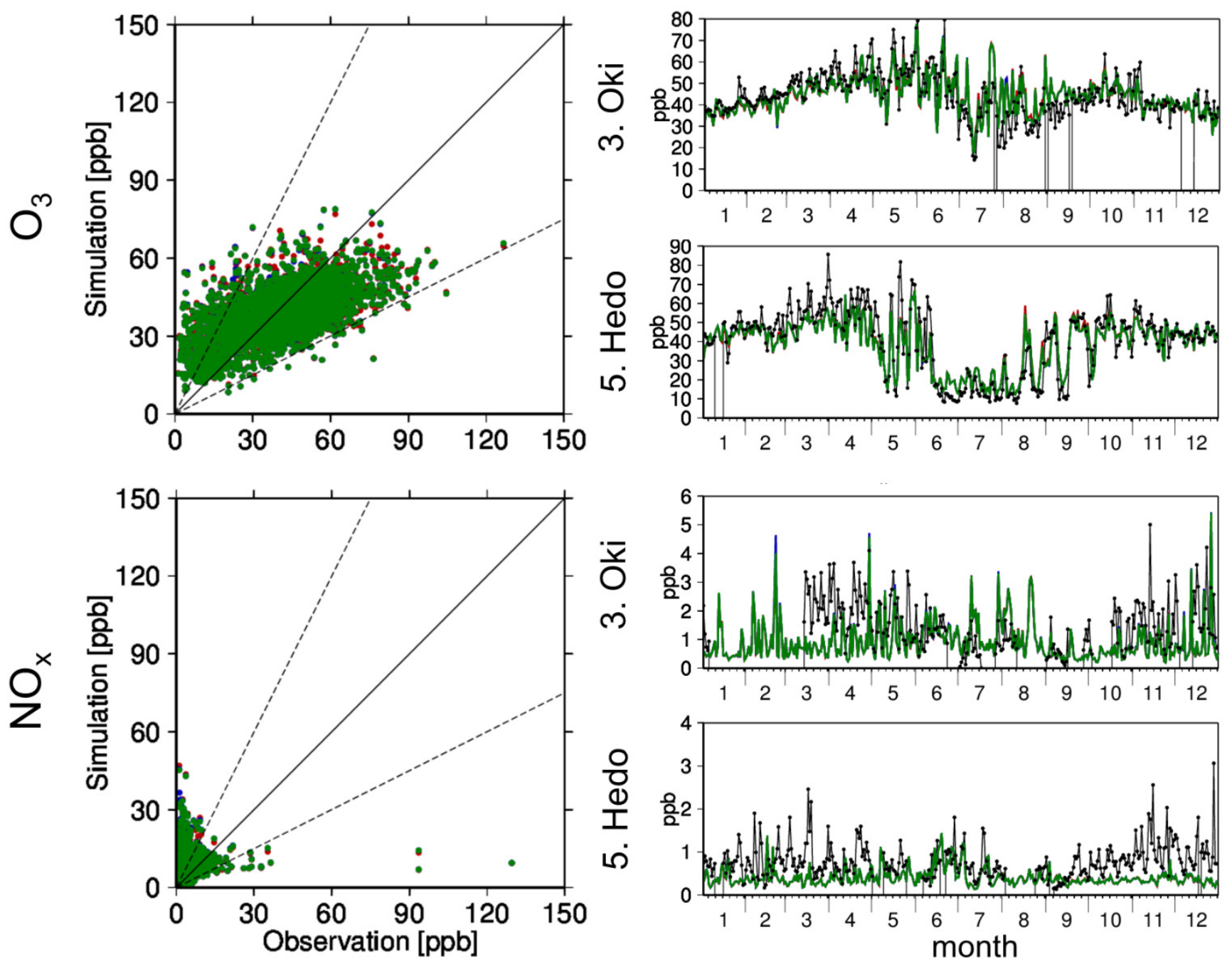

Figure S3-1. (left) Scatter diagrams and (right) time series of the simulated (red: bulk method, blue: 3-category method, green: 5-category method) and observed (black) daily mean surface concentrations of (top) $\mathrm{O}_{3}$ and (bottom) $\mathrm{NO}_{\mathrm{x}}$ at all Japanese EANET stations for the scatter diagrams and (above) Oki and (below) Hedo for the time series data in 2006. 
(a) Dust extinction at 10. Matsue

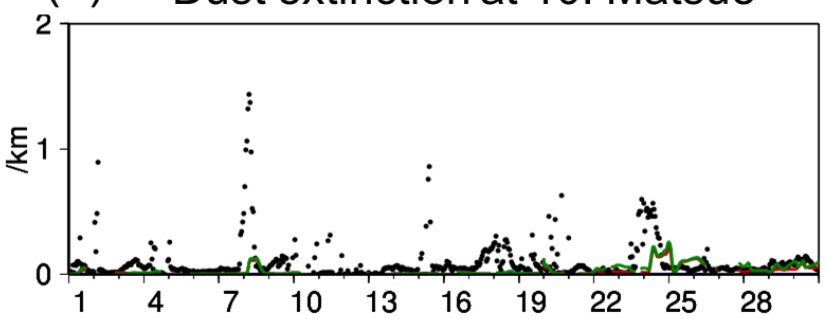

(c)

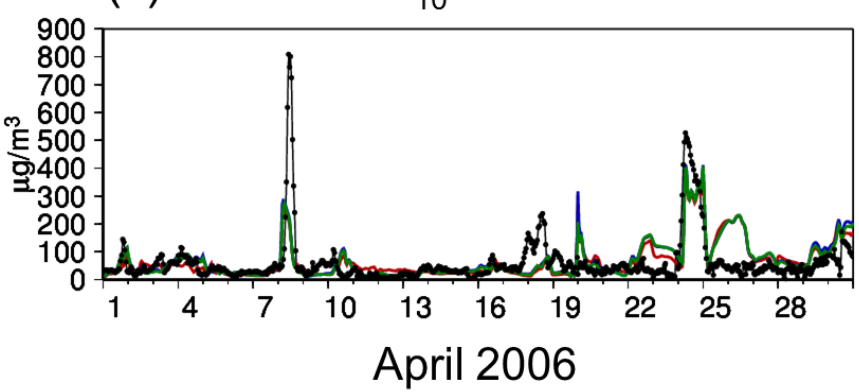

(b) Dust extinction at 5. Hedo

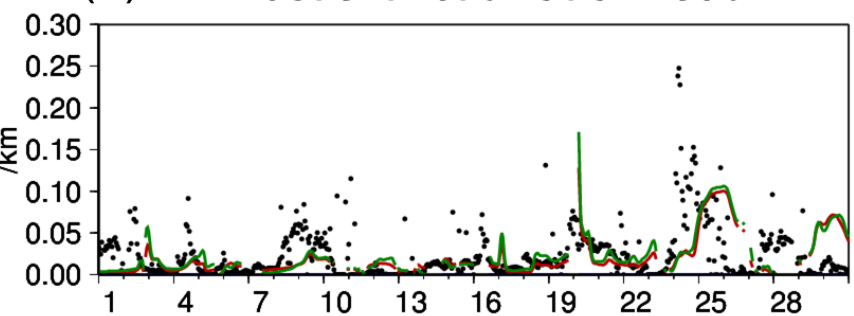

(d)

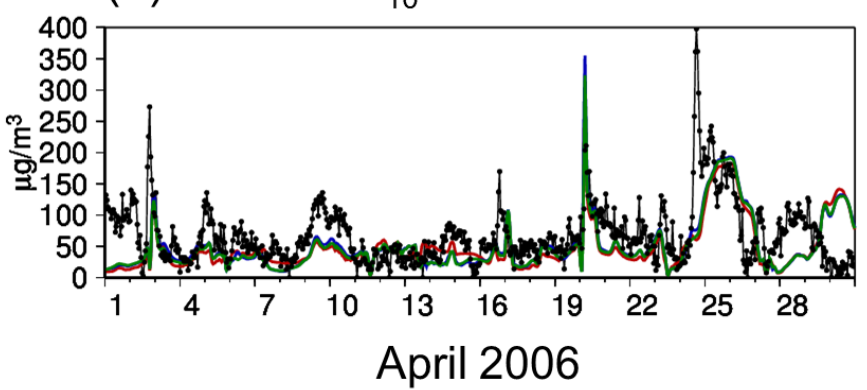

Figure S3-2. Time series of the simulated (red: bulk, blue: 3-category, green: 5-category) and observed (black) daily mean surface (top) dust extinction coefficient at the AD-Net stations and (bottom) $\mathrm{PM}_{10}$ at the EANET stations, (left) Matsue and Oki, (right) Hedo in 2006. Note that the observed dust extinction coefficient is the median value below $300 \mathrm{~m}$ above ground level (AGL).

Figure S3-2 presents the observed and simulated hourly PM10 and Ext_D at Oki/Matsue and Hedo in April 2006, when mineral dust transport events were observed. Hedo (CHAAMS) includes EANET and AD-Net, whereas Oki (Matsue) is the only EANET (AD-Net) site. The distance between Oki and Matsue is 50-60 km and there are two model grids between the nearest grids to the sites. The dust events are defined for the period in April 2006, when Ext_D and PM 10 are greater than $0.1 \mathrm{~km}^{-1}$ and $300 \mu \mathrm{g} \mathrm{m}^{-3}$ at the Oki/Matsue stations and $0.06 \mathrm{~km}^{-1}$ and $150 \mu \mathrm{g} \mathrm{m}^{-3}$ at the Hedo station. Table 4 compares the observed and simulated Ext_D and $\mathrm{PM}_{10} \mathrm{D}$ during the dust events in the month. The $R$ values for Ext_D and $\mathrm{PM}_{10} \_\mathrm{D}$ are particularly low, mainly because the values are the comparisons of hourly concentrations during the limited period (totally 69 data). The $R$ values for the daily concentrations of Ext_D and $\mathrm{PM}_{10}$ at all stations for the whole period are available in Table 4 of Kajino et al. (2019a). The $R$ value for Ext_D was still low (0.25) but that for $\mathrm{PM}_{10}$ were 0.57-0.58, comparable with other variables such as $\mathrm{PM}_{2.5}$ and $\mathrm{O}_{3}$. There are no data for Ext_D of the 3-category method because sea salt and dust particles are completely internally mixed so that the extinction coefficient of dust particles cannot be isolated from the extinction coefficient of COR, which includes abundant sea salt particles at these near-the-coast sites. 

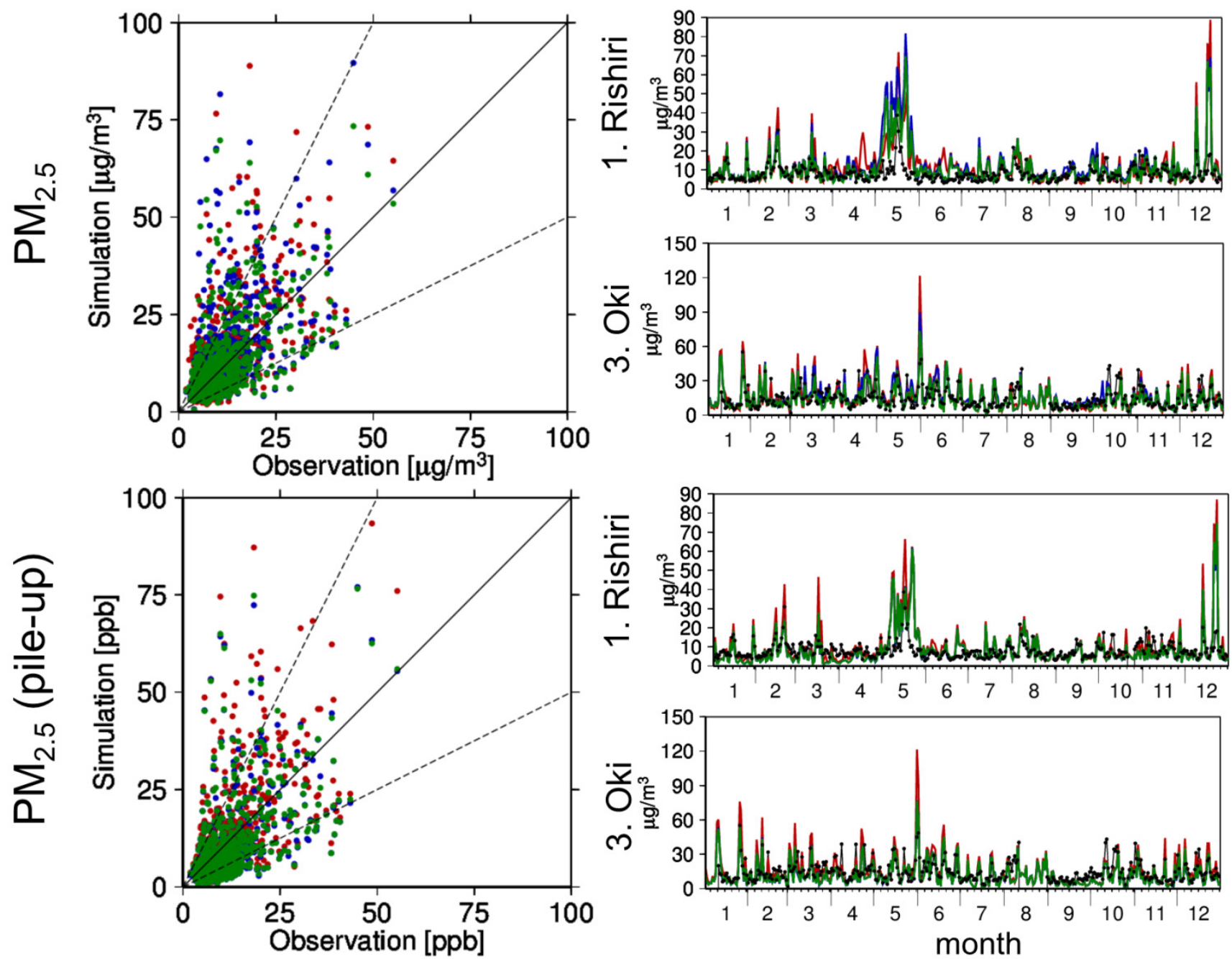

Figure S3-3. (left) Scatter diagrams and (right) time series of the simulated (red: bulk method, blue: 3-category method, green: 5-category method) and observed (black) daily mean surface concentrations of (top) $\mathrm{PM}_{2.5}$ and (bottom) $\mathrm{PM}_{2.5}$ (pileup) at the EANET stations, (above) Rishiri and (below) Oki in 2006. The scatter diagrams include Oki and Rishiri data because $\mathrm{PM}_{2.5}$ data are available at only these two stations in 2006.

The comparison between the simulated and observed $\mathrm{PM}_{2.5}$ and $\mathrm{PM}_{2.5}$ (pile-up) is shown in Fig. S3-3 and listed in Table 4. The performances of simulated $\mathrm{PM}_{2.5}$ were comparable or slightly better than those of $\mathrm{PM}_{2.5}$ (pile-up), indicating consistent prediction of the aerosol size distributions. The $R$ values of $\mathrm{PM}_{2.5}$ and $\mathrm{PM}_{2.5}$ (pile-up) were similar. The Sim:Obs of the 3-category $\mathrm{PM}_{2.5}$ (1.22) was larger than those of the other two methods due to the complete internal mixing assumption of the sea salt and dust particles in the 3-category method as mentioned in Sect. 6.2. Table 4 shows that the Sim:Obs of $\mathrm{PM}_{2.5}$ was greater than that of $\mathrm{PM}_{2.5}$ (pile-up), indicating that approximately $20 \%$ of the sea salt (and $40 \%$ of the 
dust/sea salt mixture) contributed to the $\mathrm{PM}_{2.5}$ at Oki and Rishiri. Although they have not yet been discussed, there are still large discrepancies in the simulated and observed $\mathrm{PM}_{2.5}$ chemical compositions in Japan. Because the uncertainties in both the simulated chemical compositions and their size distributions contribute to the simulated $\mathrm{PM}_{2.5}$, it is not necessary for the 5-category method to yield the best prediction of $\mathrm{PM}_{2.5}$. In fact, the $R$ value of $\mathrm{PM}_{2.5}(0.62)$ predicted by the bulk method was slightly higher than those of both the $\mathrm{PM}_{2.5}$ and $\mathrm{PM}_{2.5}$ (pile-up) of the 3- and 5-category methods (0.57-0.58) (Table 4). However, the current analysis is insufficient because the simulated $\mathrm{PM}_{2.5}$ was compared with observations obtained at only two stations on remote islands. Currently, evaluation of predicted $\mathrm{PM}_{2.5}$ at various locations is ongoing under the framework of a multimodel intercomparison study in Japan called J-STREAM (Chatani et al., 2018).

3. Oki
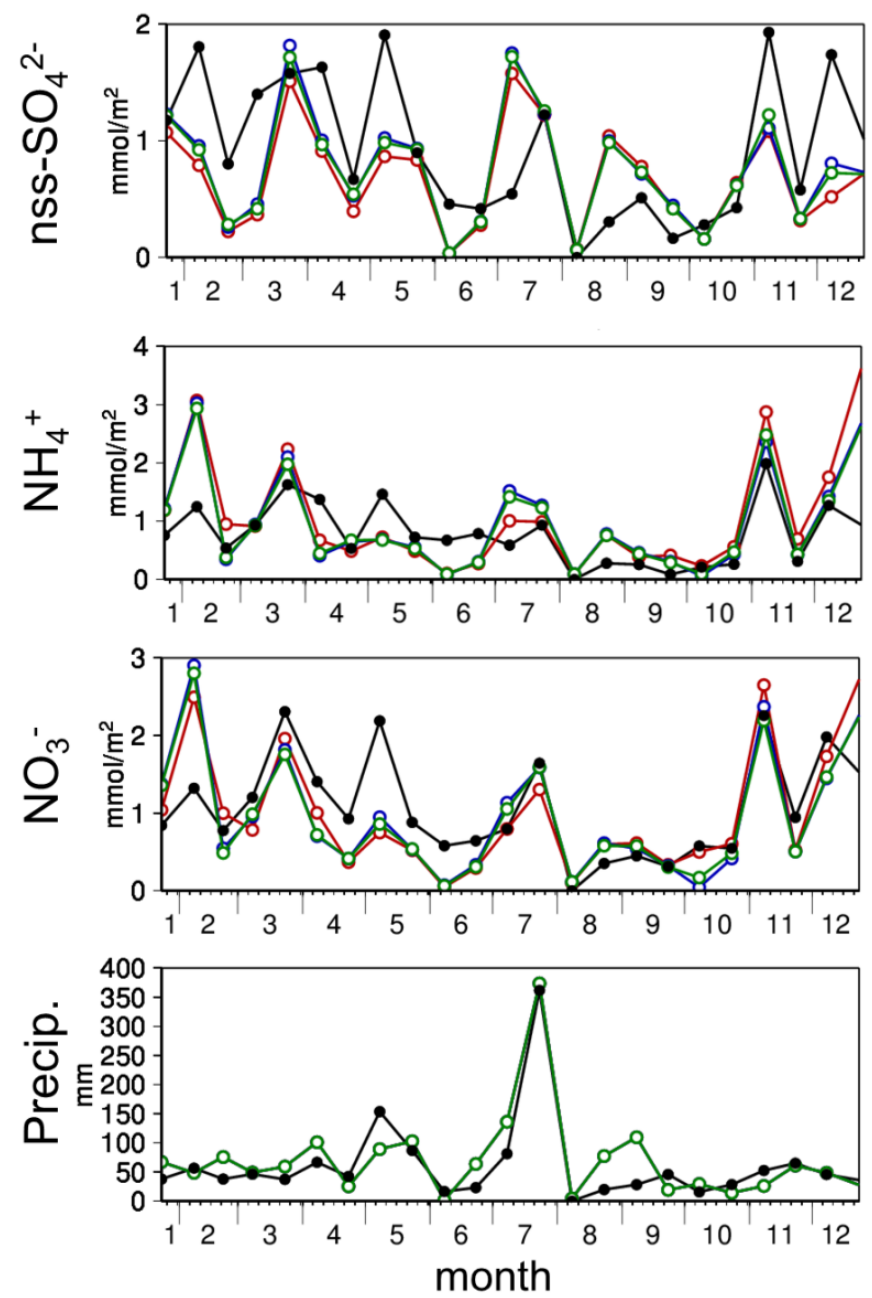

5. Hedo
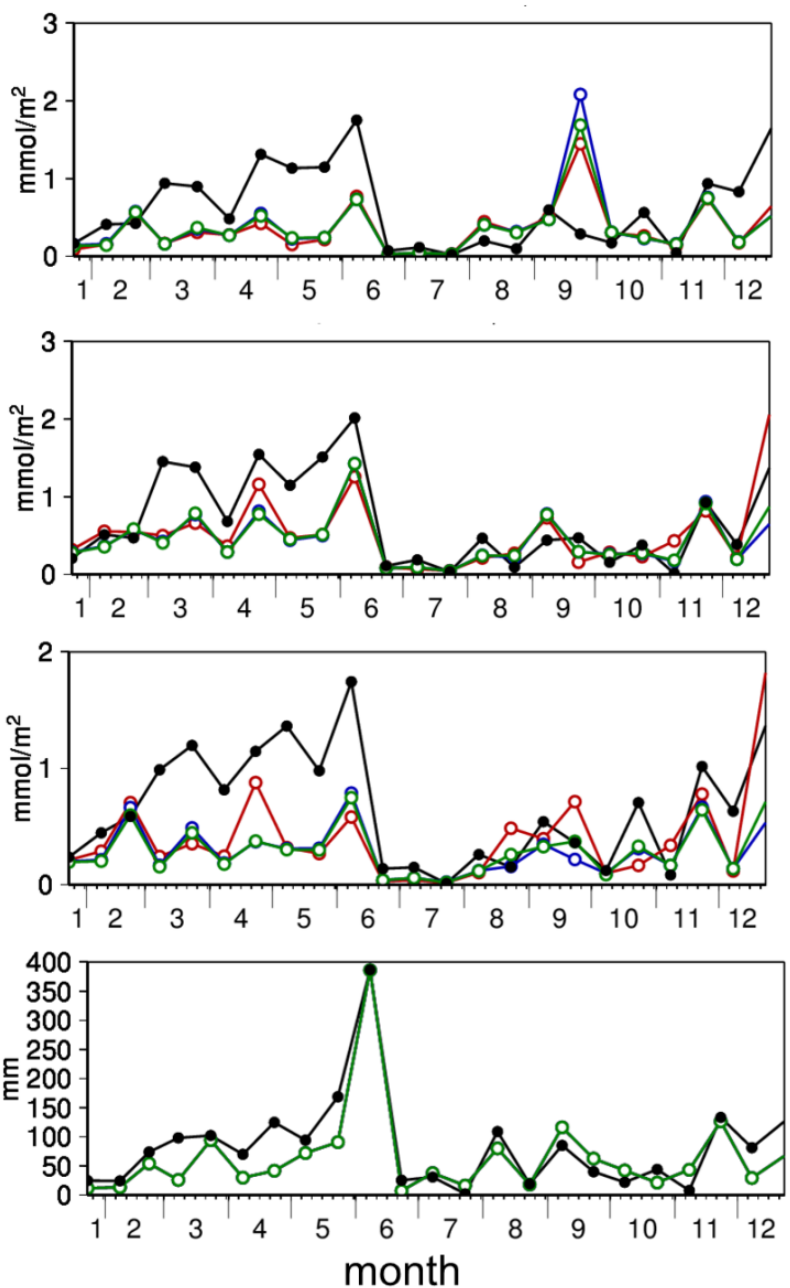

Figure S3-4. The simulated (red: bulk method, blue: 3-category method, green: 5-category method) and observed (black) half-monthly mean (top to bottom) wet deposition amounts of nss- $\mathrm{SO}_{4}{ }^{2-}, \mathrm{NH}_{4}{ }^{+}$, and $\mathrm{NO}_{3}^{-}$and precipitation at (left) Oki and (right) Hedo in 2006. 
AOT
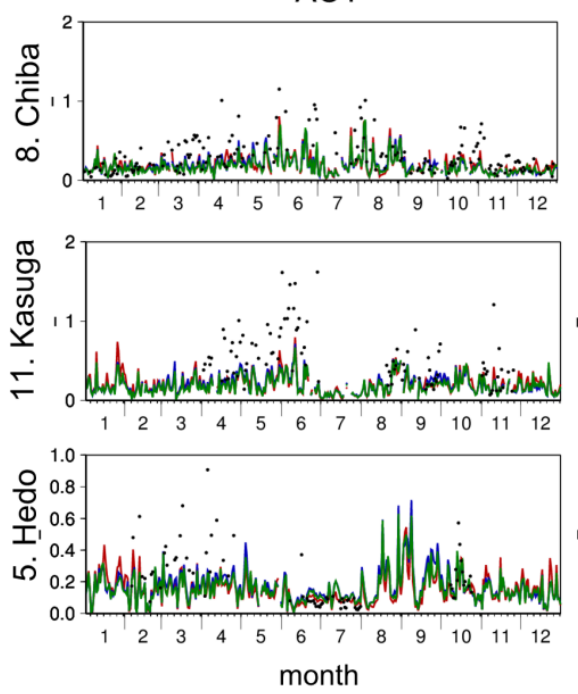

SSA
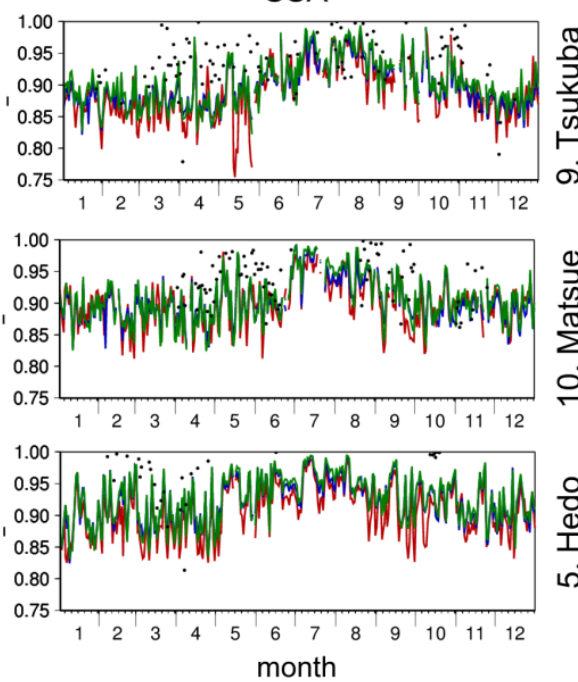

Ext_T
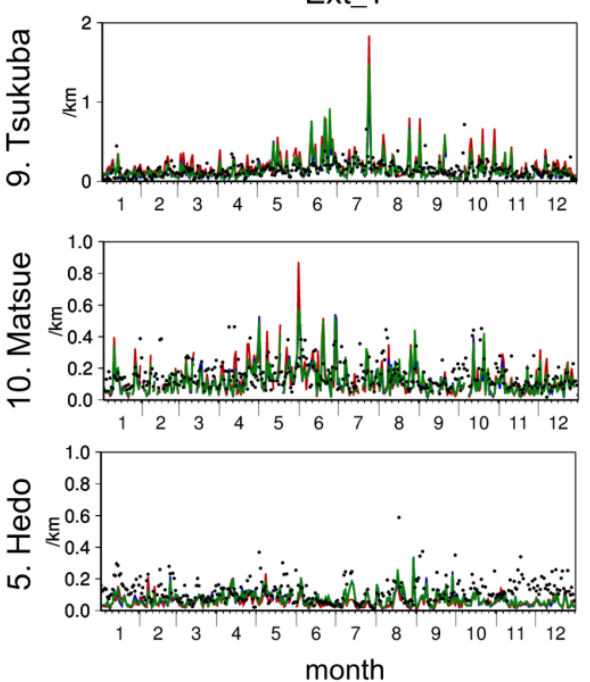

Figure S3-5. The simulated (red: bulk method, blue: 3-category method, green: 5-category method) and observed (black) daily mean (left to right) AOT and SSA of SKYNET and Ext_T of AD-Net at (top) Chiba and Tsukuba, (middle) Kasuga and Matsue, and (bottom) Hedo in 2006. Note that the observed Ext_T is the median value below $300 \mathrm{~m}$ AGL, while that simulated is the surface value.

Figure S3-4 shows wet deposition amounts of $\mathrm{SO}_{4}{ }^{2-}, \mathrm{NO}_{3}{ }^{-}$, and $\mathrm{NH}_{4}{ }^{+}$and precipitation amounts at Oki and Hedo. As shown in Table 4, the model precipitation predictions by NHM and the wet deposition amounts predicted by Chem are similar: $10-15 \%$ underestimation, approximately 0.7 of $R$, and 0.6 of $\mathrm{Fa}$, except 0.5 of $R$ for wet deposition of nss- $\mathrm{SO}_{4}{ }^{2-}$ ). A similar feature, underestimation of the wet deposition amounts, is found in Fig. S3-4. Certainly, this is not likely the only reason for the lower $R$ for nss- $\mathrm{SO}_{4}{ }^{2-}$, which could also be due to the effect of short-lived large sea salt particles, as discussed in Kajino et al. (2012b). Because the Japanese EANET stations are located near the coasts (150-700 $\mathrm{m}$ from the coastline), the observed amount of $\mathrm{W}-\mathrm{Na}^{+}$could be substantially affected by the short-lived (traveling distance is approximately $1 \mathrm{~km}$ ) large sea salt particles $(D>10 \mu \mathrm{m})$, which is not considered in the model. As a result, the simulated $\mathrm{W}-\mathrm{Na}^{+}$substantially underestimated the observation ( $\mathrm{Sim}: \mathrm{Obs}=0.26-0.27$ ). This discrepancy in $\mathrm{Na}^{+}$slightly lowered the $R$ of nss- $\mathrm{SO}_{4}{ }^{2-}$ compared to those of the other chemical components and precipitation ( $\mathrm{Sim}: \mathrm{Obs}$ of total (non-sea salt plus sea salt)-SO $\mathrm{SO}_{4}{ }^{2-}=$ 0.42-0.44). $\mathrm{SO}_{4}{ }^{2-}$ from dimethyl sulfide (DMS), which was not considered in the simulation, could be a reason for the discrepancy, but the contribution may not be large for the region of the simulation (e.g., Kajino et al., 2004).

The Fig. S3-5 compares the simulated and observe daily variations of AOT, SSA, and Ext_T and the statistical scores are listed in Table 4. The simulated AOT was underestimated by 50-60\% (Table 4). There may be two reasons for this underestimation: the underestimation of upper atmospheric aerosol concentrations or the overestimation of the ratios of mass concentration to extinction coefficient (MEF: the mass/extinction conversion factor, as defined in Sugimoto et al., 2011). Considering that the simulated mass $\left(\mathrm{PM}_{2.5}, \mathrm{PM}_{2.5}\right.$ (pile-up), and $\left.\mathrm{PM}_{10}\right)$ quantitatively agreed with the observed mass ( $\left.\mathrm{PM}_{2.5}\right)$ 
or slightly underestimated the observed mass by $20-30 \%\left(\mathrm{PM}_{2.5}\right.$ (pile-up) and $\left.\mathrm{PM}_{10}\right)$ and that the degrees of underestimations of AOT and Ext_T were similar (50-60\% and 45-50\%, respectively), the underestimation of Ext_T could be due to the overestimation of MEF. The simulated SSA was underestimated by $5-10 \%$, with an observed median of 0.96 (Table 4). Therefore, the values in Fig. 8 (AOT within $1 \mathrm{~km}$ ) could be underestimated by approximately 50\%, whereas the values in Fig. 9 (AAOT within $1 \mathrm{~km}$ ) could be overestimated by 50-100\%. One of the main purposes of the development of the 5category method was to more realistically simulate the physical and chemical properties of BC-containing particles. The statistical scores of SSA predicted by the 5-category method are better than those predicted by the other two methods, which could support consistent implementation of the 5-category method.

There are no $\mathrm{CCN}$ observation data available for the year, but the $\mathrm{NC}_{0.3}$ observed by $\mathrm{OPC}$ was used alternatively for the model evaluations of simulated CCN. The critical diameter of $0.3 \mu \mathrm{m}$ corresponds to $0.035-0.041 \%$ of the critical supersaturations for $\kappa$ of 0.3-0.4 (Petters and Kreidenweis, 2007). The OPC data are only available from March to April and November to December 2006 at Hedo. The statistical scores for $\mathrm{NC}_{0.3}$ are listed in Table 4. Those of $\mathrm{PM}_{10}$ for the same period are also shown in Table 4 to compare the model performance for the prediction of number concentration against that of mass concentrations. The time series data are presented in Fig. S3-6. The simulated $\mathrm{NC}_{0.3}$ overestimated the observation by $20-50 \%$, especially for the peak concentrations (Fig. S3-6). The 3-category and 5-category methods successfully avoided the significant overestimations of the peak concentrations predicted by the bulk method, which indicates consistent implementations of aerosol dynamic processes of the 3-category and 5-category methods. $\mathrm{PM}_{10}$ at Hedo could be substantially affected by sea salt particles, whereas $\mathrm{NC}_{0.3}$ could be controlled by the number of submicron particles. Thus, it is hard to evaluate the number-mass consistency with the available data, but we can safely conclude that the prediction of number concentration was more difficult than that of mass concentration, as the $R$ results of $0.29-0.36$ for number concentration was smaller than those for mass concentration (0.52-0.55) (Table 4). 

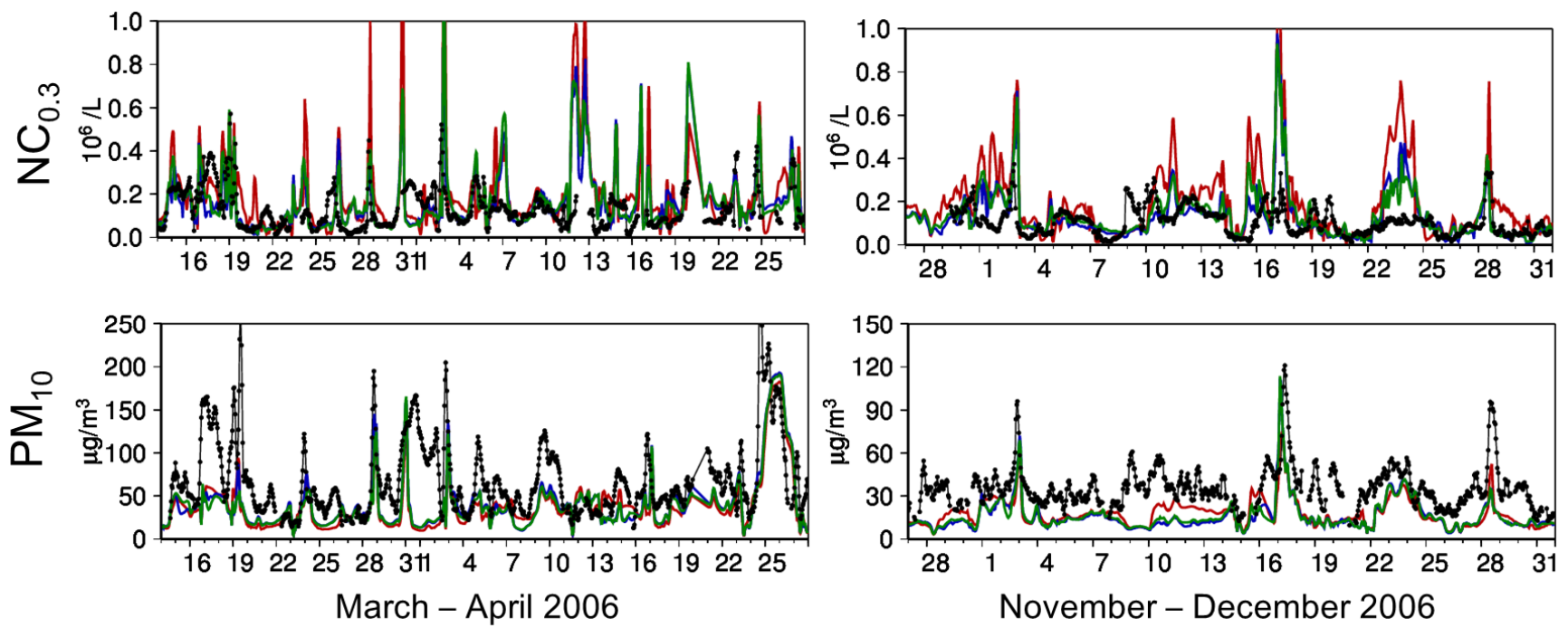

Figure S3-6. The simulated (red: bulk method, blue: 3-category method, green: 5-category method) and observed (black) hourly (top) $\mathrm{NC}_{0.3}$ and (bottom) $\mathrm{PM}_{10}$ at Hedo, when the OPC data are available, namely, (left) March 14 to 27 and (right) November 27 to December 31 of 2006. A 5-hour running mean is used to draw the lines of the observed $\mathrm{PM}_{10}$, as the raw data fluctuate. Hourly values are used for the statistical comparison in Table 4. 


\section{Supplement 4}

Supplement 4 shows the seasonal mean surface air concentration of $\mathrm{PM}_{2.5}$ (pile-up) predicted by the 5-category, 3-category, and bulk methods. Discussion regarding the figure is made in the main text.
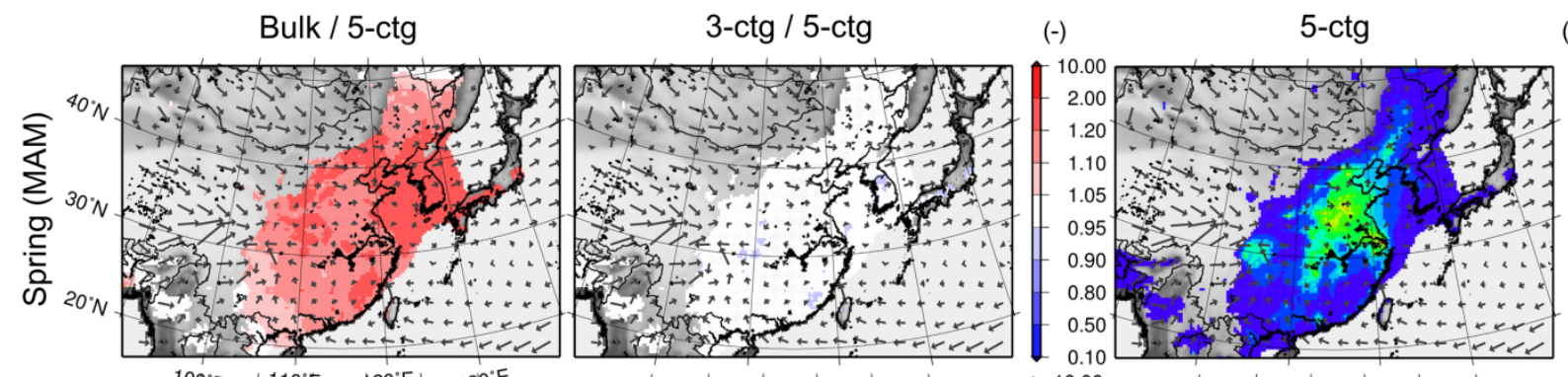

$\left(\mu \mathrm{g} / \mathrm{m}^{3}\right) \quad(\mathrm{m})$
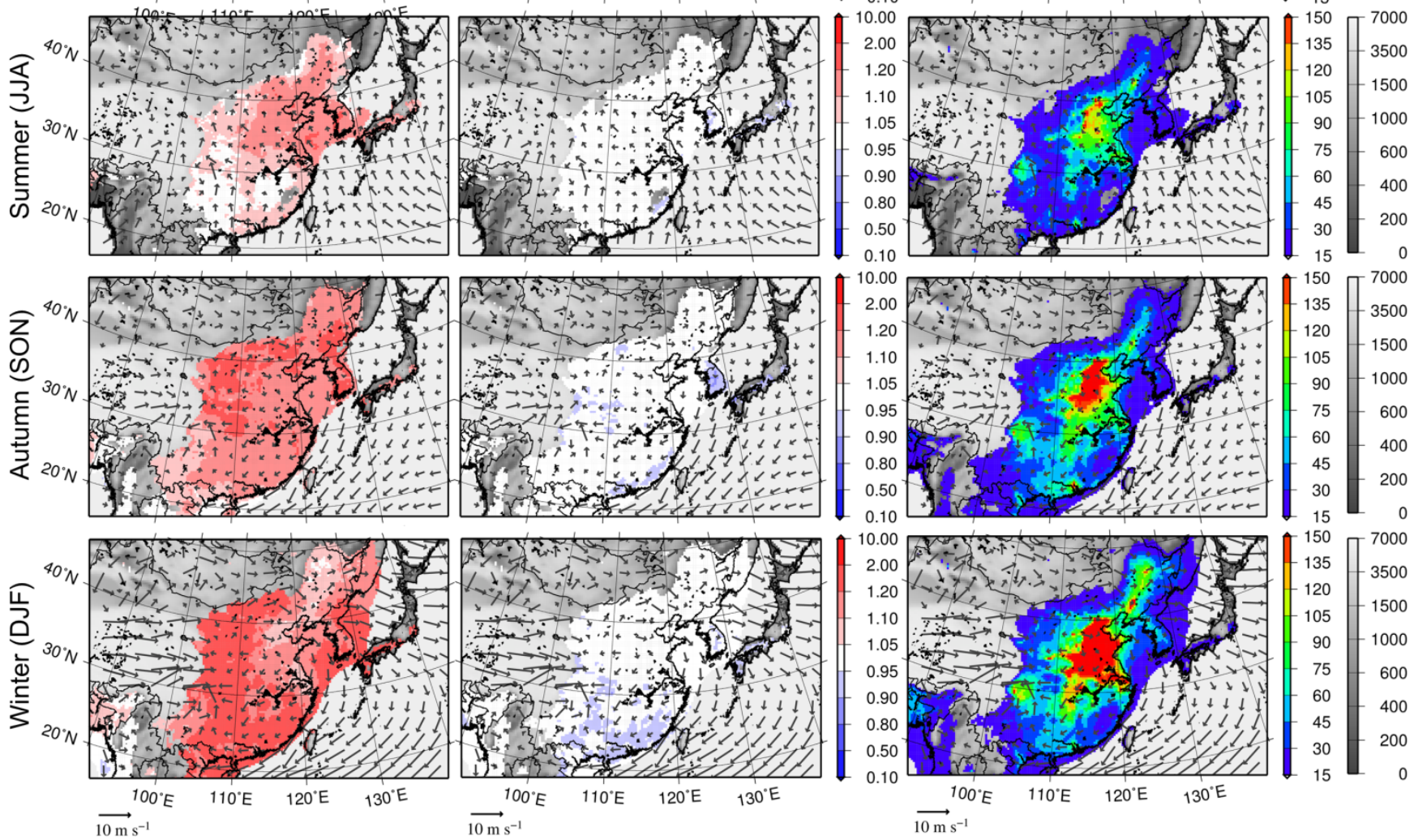

Figure S4-1. Same as Fig. 5 but for $\mathrm{PM}_{2.5}$ (pile-up). 


\section{Supplement 5}

Figure S5-1 shows the fog deposition amounts of sum of nss- $\mathrm{SO}_{4}{ }^{2-}, \mathrm{T}_{-} \mathrm{NH}_{4}{ }^{+}$, and $\mathrm{T}_{-} \mathrm{NO}_{3}{ }^{-}$, predicted by the 5-category, 3category, and bulk methods. The fog deposition amounts were generally 1-2 orders of magnitude smaller than those of the dry and wet depositions. The fog deposition amounts of the bulk method are remarkably smaller than those of the other nonequilibrium methods. This is simply because submicron aerosols are smaller in the bulk method because the aerosol microphysical processes are not taken into account. Thus, a major proportion of the submicron aerosols of the bulk method cannot be activated as fog droplets with such low supersaturation conditions for fog formation. The fog occurrence was higher in the colder seasons, and thus, the deposition areas were smallest in the summer, except in Taiwan. In Taiwan, fog deposition was highest in the summer. Larger deposition areas are found over the high topography with highly vegetated regions in the spring, autumn, and winter. The largest deposition areas are observed over the North China Plain in the winter, associated with the increase in the radiation fog frequency and air pollution levels in winter.

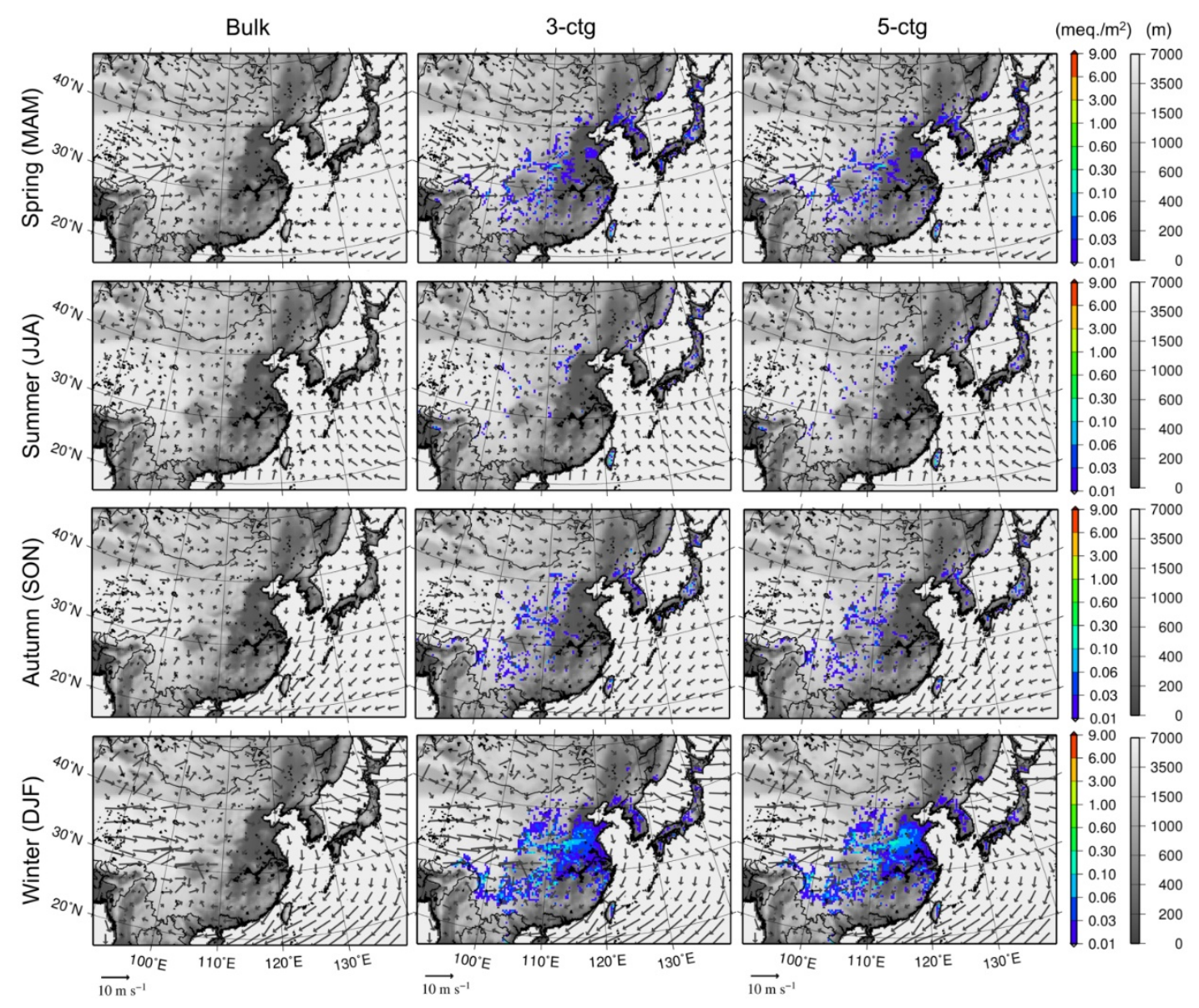

Figure S5-1. Seasonal mean fog depositions of sum of nss- $\mathrm{SO}_{4}{ }^{2-}, \mathrm{T}_{-} \mathrm{NH}_{4}{ }^{+}$, and $\mathrm{T}_{-} \mathrm{NO}_{3}{ }^{-}$in (top to bottom) spring, summer, autumn, and winter of 2006 for (left to right) the bulk, the 3-category, and the 5-category methods. 


\section{References}

Abdul-Razzak, H. and Ghan, S. J.: A parameterization of aerosol activation. 2. Multiple aerosol types. J. Geophys. Res., 105, 6837-6844, 2000.

Andres R. J. and Kasgnoc, A. D.: A time-averaged inventory of subaerial volcanic sulfur emissions. J. Geophys. Res., 103(D19), 25,251-25,261, 1998

Andronache, C., Grönholm, T., Laakso, L., Phillips, V., and Venäläinen, A.: Scavenging of ultrafine particles by rainfall at a boreal site: observations and model estimations. Atmos. Chem. Phys., 6, 4739-4754, 2006.

Aranami, K., Hara, T., Ikuta, Y., Kawano, K., Matsubayashi, K., Kusabiraki, H., Ito, T., Egawa, T., Yaashita, K., Ota, Y., Ishikawa, Y. Fujita, T., and Ishida, J.: A new operational regional model for convection-permitting numerical weather prediction at JMA, CAS/JSC WGNE Research Activities in Atmospheric and Oceanic Modelling, 5, 5-6, 2015.

Byun, D., and Schere K.: Review of the governing equations, computational algorithms, and other components of the Models-3 Community Multiscale Air Quality (CMAQ) modeling system. Appl. Mech. Rev., 59, 51-77, 2006.

Carlton, A. G., Turpin, B. J., Altieri, K. E., Seitzinger, S., Reff, A., Lim, H.-J., and Ervens, B.: Atmospheric oxalic acid and SOA production from glyoxal: Results of aqueous photooxidation experiment. Atmos. Environ., 41, 7588-7602, 2007.

Carter, W.: Documentation of the SAPRC-99 chemical mechanism for VOC reactivity assessment. Final report to California Air Resources Board, Rep. 92-329, Univ. of Calif., Riverside, 8 May, 569 pp, 2000.

Chapman, E. G., Gustafson Jr. W. I., Easter, R. C., Barnard, J. C., Ghan, S. J., Pekour, M. S., and Fast, J. D.: Coupling aerosol-cloud-radiative processes in the WRF-Chem model: Investigating the radiative impact of elevated point sources. Atmos. Chem. Phys., 9, 945-964, 2009.

Chatani, S., Yamaji, K., Sakurai, T., Itahashi, S., Shimadera, H., Kitayama, K., and Hayami, H.: Overview of Model InterComparison in Japan's Study for Reference Air Quality Modeling (J-STREAM). Atmosphere, 9(1), 19, 14 pp, 2018.

Chen, L., Gao, Y., Zhang, M., Fu, J. S., Zhu, J., Liao, H., Li, J., Huang, K., Ge, B., Wang, X., Lam, Y. F., Lin, C.-Y., Itahashi, S., Nagashima, T., Kajino, M., Yamaji, K., Wang, Z., and Kurokawa, J.: MICS-Asia III: multi-model comparison and evaluation of aerosol over East Asia, Atmos. Chem. Phys., 19, 11911-11937, https://doi.org/10.5194/acp-19-11911-2019, 2019.

Clarke, A. D., Owens, S. R., and Zhou, J.: An ultrafine sea-salt flux from breaking waves: Implications for cloud condensation nuclei in the remote marine atmosphere. J. Geophys. Res., 111, D06202, 14 pp, 2006.

Deushi, M. and Shibata, K.: Development of an MRI Chemistry-Climate Model ver.2 for the study of tropospheric and stratospheric chemistry. Papers in Meteor. Geophys., 62, 1-46, 2011.

Donahue, N. M., Robinson, A. L., Stanier, C. O., and Pandis, S. N.: Coupled partitioning, dilution, and chemical aging of semivolatile organics. Environ. Sci. Technol., 40, 2635-2643, 2006.

Edney, E. O., Kleindienst, T. E., Lewandowski, M., and Offenberg, J. H.: Updated SOA chemical mechanism for the Community Multiscale Air Quality model. EPA 600/X-07/025, US Environ. Prot. Agency, Durham, NC, 2007. 
Fountoukis, C. and Nenes, A.: ISORROPIA II: a computationally efficient thermodynamic equilibrium model for $\mathrm{K}^{+}-\mathrm{Ca}^{2+}-$ $\mathrm{Mg}^{2+}-\mathrm{NH}^{4+}-\mathrm{Na}^{+}-\mathrm{SO}_{4}{ }^{2-}-\mathrm{NO}_{3}{ }^{-}-\mathrm{Cl}^{-}-\mathrm{H}_{2} \mathrm{O}$ aerosols. Atmos. Chem. Phys., 7, 4639-4659, 2007.

Fukui, T., Kokuryo, K., Baba, T., and Kannari, A.: Updating EAGrid2000-Japan emissions inventory based on the recent emission trends. J. Jpn. Soc. Atmos. Environ., 49(2), 117-125, 2014 (in Japanese).

Ge, B., Itahashi, S., Sato, K., Xu, D., Wang, J., Fan, F., Tan, Q., Fu, J. S., Wang, X., Yamaji, K., Nagashima, T., Li, J., Kajino, M., Liao, H., Zhang, M., Wang, Z., Li, M., Woo, J.-H., Kurokawa, J., Pan, Y., Wu, Q., Liu, X., and Wang, Z.: MICS-Asia III: Multi-model comparison of reactive Nitrogen deposition over China, Atmos. Chem. Phys. Discuss., https://doi.org/10.5194/acp-2019-1083, in review, 2020.

Giglio, L., Randerson, J. T., van der Werf, G. R., Kasibhatla, P. S., Collatz, G. J., Morton, D. C., and DeFries, R. S.: Assessing variability and long-term trends in burned area by merging multiple satellite fire products. Biogeosciences, 7 , 1171-1186, 2010.

Grell, G. A., Peckham, S. E., Schmitz, R., McKeen, S. A., Frost, G., Skamarock, W. C., and Eder, B.: Fully coupled "online" chemistry within the WRF model. Atmos. Environ., 39, 6957-6975, 2005.

Guenther, A., Karl, T., Harley, P., Wiedinmyer, C., Palmer, P. I., and Geron, C.: Estimates of global terrestrial isoprene emissions using MEGAN (Model of Emissions of Gases and Aerosols from Nature). Atmos. Chem. Phys., 6 , 3181-3210, 2006.

Han, Z., Ueda, H., Matsuda, K., Zhang, R.., Arao, K., Kanai, Y., and Hasome, H.: Model study on particle size segregation and deposition during Asian dust events in March 2002. J. Geophys. Res., 109, D19205, 22 pp, 2004.

Ishikawa, H.: Mass-consistent wind model as a meteorological preprocessor for tracer transport models. J. Appl. Meteorol., 33, 733-743, 1994.

Itahashi, S., Ge, B., Sato, K., Fu, J. S., Wang, X., Yamaji, K., Nagashima, T., Li, J., Kajino, M., Liao, H., Zhang, M., Wang, Z., Li, M., Kurokawa, J., Carmichael, G. R., and Wang, Z.: MICS-Asia III: overview of model intercomparison and evaluation of acid deposition over Asia, Atmos. Chem. Phys., 20, 2667-2693, https://doi.org/10.5194/acp-20-2667-2020, 2020.

Jacob, D. J.: Heterogeneous chemistry and tropospheric ozone. Atmos. Environ., 34, 2131-2159, 2000.

JMA: The next generation non-hydrostatic model ASUCA. Suuchi Yohoka Hokoku Bessatsu (Additonal Volume to Report of Numerical Prediction Division) 60, 151 pp., 2014 (in Japanese)

Kajino, M., Ueda, H., Satsumabayashi, H., and An, J.: Impacts of the eruption of Miyakejima Volcano on air quality over far east Asia. J. Geophys. Res., 109, D21204, 11 pp, 2004.

Kajino, M.: MADMS: Modal Aerosol Dynamics model for multiple Modes and fractal Shapes in the free-molecular and near-continuum regimes. J. Aerosol Sci., 42, 224-248, 2011.

Kajino, M. and Kondo, Y.: EMTACS: Development and regional-scale simulation of a size, chemical, mixing type, and soot shape resolved atmospheric particle model. J. Geophys. Res., 116, D02303, 28 pp, 2011. 
Kajino, M., Inomata, Y., Sato, K., Ueda, H., Han, Z., An, J., Katata, G., Deushi, M., Maki, T., Oshima, N., Kurokawa, J., Ohara, T., Takami, A., and Hatakeyama, S.: Development of the RAQM2 aerosol chemical transport model and predictions of the Northeast Asian aerosol mass, size, chemistry, and mixing type. Atmos. Chem. Phys., 12, 11833-11856, $2012 \mathrm{a}$.

Kajino, M., Deushi, M., Maki, T., Oshima, N., Inomata, Y., Sato, K., Ohizumi, T., and Ueda, H.: Modeling wet deposition and concentration of inorganics over Northeast Asia with MRI-PM/c. Geosci. Model Dev., 5, 1363-1375, 2012b.

Kajino, M., Deushi, M., Sekiyama, T. T., Oshima, N., Yumimoto, K., Tanaka, T. Y., Ching, J., Hashimoto, A., Yamamoto, T., Ikegami, M., Kamada, A., Miyashita, M., Inomata Y., Shima S., Adachi, K., Zaizen, Y., Igarashi, Y., Ueda, H., Maki, T., and Mikami, M.: NHM-Chem, the Japan Meteorological Agency's regional meteorology-chemistry model (v1.0): model description and aerosol representations, Geosci. Model Dev. Discuss., https://doi.org/10.5194/gmd-2018-128, 2018.

Kajino, M., Sekiyama, T. T., Igarashi, Y., Katata, G., Sawada, M., Adachi, K., Zaizen, Y., Tsuruta, H., Nakajima, T.: Deposition and dispersion of radio-cesium released due to the Fukushima nuclear accident: Sensitivity to meteorological models and physical modules, J. Geophys. Res., 124, 1823-1845, doi:10.1029/2018JD028998, 2019.

Kannari, A., Tonooka, Y., Baba, T., and Murano, K.: Development of multiple-species $1 \mathrm{~km} \times 1 \mathrm{~km}$ resolution hourly basis emissions inventory for Japan. Atmos. Environ., 41, 3428-3439, 2007.

Katata, G., Nagai, H., Wrzesinsky, T., Klemm, O., Eugster, W., and Burkard, R.: Development of a land surface model including cloud water deposition on vegetation. J. Appl. Meteo. Clim., 47, 2129-2146, 2008.

Katata, G., Nagai, H., Zhang, L., Held, A., Serça, D., and Klemm, O.: Development of an atmosphere-soil-vegetation model for investigation of radioactive materials transport in the terrestrial biosphere. P. Nucl. Sci. Technol., 2, 530-537, 2011a.

Katata, G., Kajino, M., Hiraki, T., Aikawa, M., Kobayashi, T., and Nagai, H.: A method for simple and accurate estimation of fog deposition in a mountain forest using a meteorological model. J. Geophys. Res., 116, D20102, 2011 b.

Katata, G., Chino, M., Kobayashi, T., Terada, H., Ota, M., Nagai, H., Kajino, M., Draxler, R., Hort, M. C., Malo, A., Torii, T., and Sanada. Y.: Detailed source term estimation of the atmospheric release for the Fukushima Daiichi Nuclear Power Station accident by coupling simulations of an atmospheric dispersion model with an improved deposition scheme and oceanic dispersion model. Atmos. Chem. Phys., 15, 1029-1070, 2015.

Kong, L., Tang, X., Zhu, J., Wang, Z., Fu, J. S., Wang, X., Itahashi, S., Yamaji, K., Nagashima, T., Lee, H.-J., Kim, C.-H., Lin, C.-Y., Chen, L., Zhang, M., Tao, Z., Li, J., Kajino, M., Liao, H., Wang, Z., Sudo, K., Wang, Y., Pan, Y., Tang, G., Li, M., Wu, Q., Ge, B., and Carmichael, G. R.: Evaluation and uncertainty investigation of the NO2, CO and NH3 modeling over China under the framework of MICS-Asia III, Atmos. Chem. Phys., 20, 181-202, https://doi.org/10.5194/acp-20-181-2020, 2020.

Kuang, C., McMurry, P. H., McCormick, A. V., and Eisele, F. L.: Dependence of nucleation rates on sulfuric acid vapor concentration in diverse atmospheric locations. J. Geophys. Res., 113, D10209, 9 pp, 2008. 
Kunii, M.: Mesoscale data assimilation for a local severe rainfall event with the NHM-LETKF system. Wea. Forecasting, 29 , 1093-1105, 2014.

Kurokawa, J., Ohara, T, Morikawa, T., Hanayama, S., Janssens-Maenhout, G., Fukui, T., Kawashima, K., and Akimoto, H.: Emissions of air pollutants and greenhouse gases over Asian regions during 2000-2008: Regional Emission inventory in ASia (REAS) version 2. Atmos. Chem. Phys., 13, 11019-11058, 2013.

Li, J., Nagashima, T., Kong, L., Ge, B., Yamaji, K., Fu, J. S., Wang, X., Fan, Q., Itahashi, S., Lee, H.-J., Kim, C.-H., Lin, C.Y., Zhang, M., Tao, Z., Kajino, M., Liao, H., Li, M., Woo, J.-H., Kurokawa, J., Wu, Q., Akimoto, H., Carmichael, G. R., and Wang, Z.: Model evaluation and inter-comparison of surface-level ozone and relevant species in East Asia in the context of MICS-Asia phase III Part I: overview.. Atmos. Chem. Phys., 19, 12993-13015, doi:10.5194/acp-19-129932019, 2019.

Lin, Y.-L., Farley, R. D., and Orville, H. D.: Bulk parameterization of the snow field in a cloud model. J. Appl. Meteo. Clim., 22, 1065-1092, 1983.

Lohmann, U. and Diehl, K.: Sensitivity studies of the importance of dust ice nuclei for the indirect aerosol effect on stratiform mixedphase clouds. J. Atmos. Sci., 63, 968-982, 2006.

Madronich, S.: Photodissociation in the atmosphere: 1. Actinic flux and the effects of ground reflections and clouds. J. Geophys. Res., 92, 9740-9752, 1987.

Murakami, M., Magono, C., and Kikuchi, K.: Experiments on aerosol scavenging by natural snow crystals, Part III: The effect of snow crystal charge on collection efficiency. J. Meteorol. Soc. Jpn., 63, 1127-1137, 1985.

Nishizawa, S., Yashiro, H., Sato, Y., Miyamoto, Y., and Tomita, H.: Influence of grid aspect ratio on planetary boundary layer turbulence in large-eddy simulations, Geosci. Model Dev., 8, 3393-3419, doi:10.5194/gmd-8-3393-2015, 2015.

Oshima, N., Koike, M., Zhang, Y., Kondo, Y., Moteki, N., Takegawa, N., and Miyazaki, Y.: Aging of black carbon in outflow from anthropogenic sources using a mixing state resolved model: Model development and evaluation. J. Geophys. Res., 114, D06210, 2009a.

Petters, M. D. and Kreidenweis, S. M.: A single parameter representation of hygroscopic growth and cloud condensation nucleus activity. Atmos. Chem. Phys., 7, 1961-1971, 2007.

Pleim, J. E. and Chang, J. S.: A non-local closure model for vertical mixing in the convective boundary layer. Atmos. Environ., 26A, 965-981, 1992.

Saito, K., Fujita, T., Yamada, Y., Ishida, J., Kumagai, Y., Aranami, K., Ohmori, S., Nagasawa, R., Kumagai, S., Muroi, C., Kato, T., Eito, H., and Yamazaki, Y.: The operational JMA nonhydrostatic mesoscale model. Mon. Wea. Rev., 134, 1266-1298, 2006.

Saito, K., Ishida, J., Aranami, K., Hara, T., Segawa, T., Narita, M., and Honda, Y.: Nonhydrostatic atmospheric models operational development at JMA. J. Meteor. Soc. Japan, 85B, 271-304, 2007.

Saito, K.: Chapter 5. The JMA nonhydrostatic model and its application to operation and research. Atmospheric Model Applications, Ed. Ismail Yucel, InTech Open Access Publisher, 85-110, 2012. 
Sato, Y., Nishizawa, S., Yashiro, H., Miyamoto, Y., Kajikawa, Y., and Tomita, H.: Impacts of cloud microphysics on trade wind cumulus: which cloud microphysics processes contribute to the diversity in a large eddy simulation?, Prog. Earth Planet. Sci., 2, 23, doi:10.1186/s40645-015-0053-6, 2015.

Sekiyama, T. T., Kunii, M., Kajino, M., and Shimbori, T.: Horizontal resolution dependence of atmospheric simulations of the Fukushima nuclear accident using 15-km, 3-km, and 500-m Grid Models. J. Meteor. Soc. Japan, 93, 49-64, 2015.

Skamarock, W. C., Klemp, J. B., Dudhia, J., Gill, D. O., Barker, D. M., Duda, M. G., Huang, X. Y., Wang, W., and Powers, J. G.: A description of the advanced research WRF version 3. Tech. Note, NCAR/TN 475+STR, 125 pp., Natl. Cent. for Atmos. Res., Boulder, Colo, 2008.

Slinn, W. G. N.: Precipitation scavenging, in: Atmospheric Science and Power Production. Chap. 11, edited by: Randerson, D., No. DOE/TIC-27601, US Department of Energy, Washington, DC, 466-532, 1984.

Sugimoto, N., Hara, Y., Shimizu, A., Yumimoto, K., Uno, I., and Nishikawa, M. Comparison of surface observations and a regional dust transport model assimilated with lidar network data in Asian dust event of March 29 to April 2, 2007. SOLA, 7A, 13-16, 2011.

Wong, D. C, Pleim, J., Mathur, R., Binkowski, F., Otte, T., Gilliam, R., Pouliot, G., Xiu, A., Young, J. O., and Kang, D.: WRF-CMAQ two-way coupled system with aerosol feedback: software development and preliminary results. Geosci. Model Dev., 5, 299-312, 2012.

Woo, J.-H., Streets, D. G., Carmichael, G. R., Tang, Y., Yoo, B., Lee, W.-C., Thongboonchoo, N., Pinnock, S., Kurata, G., Uno, I., Fu, Q., Vay, S., Sachse, G. W., Clake, D. R., Fried, A., and Thornton, D. C.: Contribution of biomass and biofuel emissions to trace gas distributions in Asia during the TRACE-P experiment. J. Geophys. Res., 108(D21), 8812, 2003.

Yumimoto, K. Tanaka, T. Y., Oshima, N., and Maki, T.: JRAero: the Japanese Reanalysis for Aerosol v1.0. Geosci. Model Dev., 10, 3225-3253, 2017.

Yumimoto, K., Kajino, M., Tanaka, T. Y., and Uno, I.: Dust vortex in the Taklimakan desert by Himawari-8 high frequency and resolution observation, Sci. Rep., 9:1209, 7 pp., doi:10.1038/s41598-018-37861-4, 2019.

Zaveri, R. A., Barnard, J. C., Easter, R. C., Riemer, N., and West, M.: Particle-resolved simulation of aerosol size, composition, mixing state, and the associated optical and cloud condensation nuclei activation properties in an evolving urban plume. J. Geophys. Res., 115, D17210, 2010.

Zhang, D., and Iwasaka, Y.: Size change of Asian dust particles caused by sea salt interaction: Measurements in southwestern Japan. Geophys. Res. Lett., 31, L15102, 4 pp, 2004.

Zhang, K., O’Donnell, D., Kazil, J., Stier, P., Kinne, S., Lohmann, U., Ferrachat, S., Croft, B., Quaas, J., Wan, H., Rast, S., and Feichter, J.: The global aerosol-climate model ECHAM-HAM, version 2: sensitivity to improvements in process representations, Atmos. Chem Phys. 12, 8911-8949, 2012.

Zhang, L., Gong, S., Padro, J., and Barrie, L.: A size-segregated particle dry deposition scheme for an atmospheric aerosol module. Atmos. Environ., 35, 549-560, 2001. 
Zhang, L., Brook, J. R., and Vet, R.: A revised parameterization for gaseous dry deposition in air-quality models. Atmos. Chem. Phys., 3, 2067-2082, 2003.

Zhang, L., Wang, X., Moran, M. D., and Feng, J.: Review and uncertainty assessment of size-resolved scavenging coefficient formulations for below-cloud snow scavenging of atmospheric aerosols. Atmos. Chem. Phys., 13, 1000510025, 2013.

Zhang, Y., Pan, B., Vijayaraghavan, K., Wu, S.-Y., Seigneur, C., Pandis, S. N., Jacobson, M. Z., Nenes, A., and Seinfeld, J. H.: Development and application of the Model of Aerosol Dynamics, Reaction, Ionization, and Dissolution (MADRID). J. Geophys. Res., 109, D01202, 2004.

Zhang, Y., Pan, Y., Wang, K., Fast, J. D., and Grell, G. A.: WRF/Chem-MADRID: Incorporation of an aerosol module into WRF/Chem and its initial application to the TexAQS20000 episode. J. Geophys. Res., 115, D18202, 2010. 